\title{
INTEGRASI NILAI ISLAM DALAM PEMBELAJARAN IPA (Perspektif Pendidikan Islam)
}

\author{
Novianti Muspiroh \\ IAIN Syekh Nurjati Cirebon \\ Jl. Perjuangan By Pass Sunyaragi Cirebon-Jawa Barat 4513213 \\ Email: noviantimuspiroh.ak@gmail.com
}

\begin{abstract}
ABSTRAK
Tulisan ini bertujuan mengkaji kemungkinan nilai-nilai spiritual agar terintegrasi dengan materi pelajaran-mata pelajaran umum, terutama ilmu pengetahuan alam (IPA). Metode analisis dalam tulisan ini mengadopsi prinsip-prinsip dasar pendidikan nilai dalam Islam yaitu tauhid, ilmu dan akhlak, yang berbasis pada integrasi keilmuan antara ilmu umum dengan ilmu agama (non dikotomis). Integrasi nilai-nilai Islam dalam pembelajaran IPA tersebut terwujud dalam pola pembelajaran IPA yang secara menyeluruh (integral-holistik) menghargai eksistensi IPA sebagai ilmu umum maupun studi Islam sebagai ilmu agama sekaligus merespons kebutuhan masyarakat dan keluarga. Dalam pelaksanaannya pembelajaran tersebut mengindahkan nilai-nilai tauhid, merangsang pencarian ilmu secara terus-menerus dan memperhatikan aspek-aspek moral dan akhlak mulia siswa.
\end{abstract}

Kata Kunci: Integrasi, Nilai Islam, Pembelajaran IPA.

\section{ABSTRACT}

This paper aims to examine the possibility of spiritual values that is integrated with subject-matter of general subjects, especially science (IPA). The method of analysis in this paper adopts the basic principles of values education in Islam is monotheism, science and morals, which is based on the integration of knowledge between public science with the science of religion (non-dichotomous). Integration of Islamic values in the science learning manifest in the pattern of the overall science learning (integral-holistic) appreciates the existence of a general science or science as the study of Islamic religious knowledge as well as responding to the needs of society and the family. In regard to the implementation of learning the values of unity, stimulating science search continuously and pay attention to aspects of students' moral and noble character.

Keywords: Integration, Islamic V alues, Learning of Natural sciences. 


\section{PENDAHULUAN}

Terdapat dua landasan utama dalam memasukkan nilai-nilai agama ke dalam pendidikan. Pertama, UUD 1945 (versi Amendemen), Pasal 31, ayat 3 (2002: 24) menyebutkan, "Pemerintah mengusahakan dan menyelenggarakan satu sistem pendidikan nasional, yang meningkatkan keimanan dan ketakwaan serta ahlak mulia dalam rangka mencerdaskan kehidupan bangsa, yang diatur dengan undang-undang." Kedua, pasal 31, ayat 5 yang menyebutkan, "Pemerintah memajukan ilmu pengetahuan dan teknologi dengan menjunjung tinggi nilai-nilai agama dan persatuan bangsa untuk kemajuan peradaban serta kesejahteraan umat manusia." Dua undang-undang tersebut mengisyaratkan tentang integrasi nilai-nilai agama dalam pembelajaran. Amanah konstitusi tersebut membuktikan bahwa tujuan pendidikan di Indonesia tidak hanya mengembangkan potensi dan mencerdaskan saja tetapi juga membentuk manusia yang berkarakter agamis.

Kenyataannya, di sekolah-sekolah sekarang ini lebih menekankan pada penanaman konsep, rumus, dan teori-teori. Mata pelajaran dan jam pelajaran di sekolah pun lebih didominasi oleh bidang ilmu umum, sedangkan pendidikan agama sangat minim sekali, sehingga pendidikan di Indonesia terkesan sekularisme. Apa gunanya cerdas tapi tidak berakhlak, apa gunanya menjadi nomor satu jika ternyata masih sering tawuran. Jadi, peran nilai-nilai agama menjadi sangat penting dalam setiap proses pendidikan yang terjadi di sekolah. Karena terbentuknya manusia yang beriman dan bertaqwa serta berakhlak mulia tidak mungkin terbentuk tanpa peran agama.

Pelaksanaan pendidikan di sekolah, baik di SD, SMP maupun SMA/SMK selalu mendapatkan berbagai kritik dan juga tanggapan yang bernada negatif. Terlebih masih terindikasi adanya dikotomi antara madrasah dan sekolah umum. Ada ketimpangan antara peran madrasah dengan peran sekolah umum dalam penanaman nilai-nilai Islam di kedua lembaga pendidikan tersebut. Madrasah sebagai lembaga pendidikan yang eksis di bawah payung Kemenag merupakan lembaga pemerintah yang menangani urusan agama Islam. Sebaliknya, sekolah umum yang ada saat ini tidak berurusan dengan agama Islam. Dampaknya, seolah-olah telah terjadi pembiaran terhadap generasi Islam yang ada di sekolah umum untuk menjadi generasi yang berilmu tapi tidak beriman. Bagaimanapun juga rakyat Indonesia, mayoritas memeluk agama Islam. Oleh karena besar kemungkinan siswa yang bersekolah di sekolah umum pun mayoritas beragama Islam.

Paradigma keliru yang membatasi ilmu agama pada institusi madrasah atau pesantren saja, secara perlahan akan menjauhkan siswa sekolah umum dari penanaman keimanan dan ketakwaan. Namun demikian, pihak sekolah seolah tidak menyadari hal demikian. Terjadi proses pembiaran paradigma tersebut mendoktrin pikiran penerus Islam. Visi sekolah hanya pasif pada bagaimana agar siswa lulus ujian dengan nilai yang baik. Sekolah umum hanya menjadi tempat memberikan pengajaran ilmu umum, sementara pendidikan Islam kurang diperhatikan. 
Fakta yang nampak jelas di dunia pendidikan pada sekolah hari ini adalah siswa di SD, SMP, dan SMA/SMK seolah ditekankan hanya pada improvisasi intelectual intelegence (kecerdasan intelektual) semata atau dalam kata lain pada pengembangan ranah koginitif. Memang benar bahwa, di setiap sekolah umum terdapat kurikulum dimana salah satu mata pelajaran yang diajarkan adalah Pendidikan Agama Islam (PAI) yang diharapkan mampu menstimulasi siswa pada penyadaran spiritual intelegence (kecerdasan spiritual), sayangnya Mata Pelajaran PAI tersebut kurang efektif dalam pembenahan akhlak generasi bangsa khususnya generasi Islam.

Buruknya sikap dan perilaku keberagaman sebagian peserta didik sering dikaitkan dengan kegagalan proses pendidikan karena dianggap kurang memberikan penanaman nilai moral keagamaan di sekolah. Krisis multi dimensi yang melanda bangsa Indonesia pun kerap kali dianggap sebagai bagian dari kegagalan pendidikan di Indonesia (Muhaimin, 2009: 18). Disinyalir, pendidikan, baik secara langsung atau tidak dianggap telah menumbuhkan budaya korupsi. Hal nampak dari kenyataan bahwa pembinaan mental para peserta didik masih lemah. Dalam hal tertentu praktik penyelenggaraan pendidikan pun sering penuh bernuansa korupsi, misalnya dalam proyek pengadaan barang atau sarana dan prasarana sekolah (Muhaimin, 2006: 119).

Andaikata ada materi pembelajaran keagamaan yang terdapat dalam kurikulum dan dalam pelaksanaan masih belum memberikan penanaman nilainilai spiritual yang baik terhadap perilaku siswa berarti guru mengalami kesulitan dalam mengintegrasikan agama dengan pelbagai mata pelajaran umum. Hasil studi Litbang Agama dan Diklat Keagamaan tahun 2000 menunjukkan bahwa merosotnya moral dan akhlak peserta didik disebabkan antara lain akibat kurikulum pendidikan agama yang terlampau padat materi, dan materi tersebut lebih mengedepankan aspek pemikiran ketimbang membangun kesadaran keberagamaan yang utuh (Masnun, 2007: 231). Oleh sebab itu, hal ini sering menimbulkan pertanyaan di kalangan masyarakat, tentang bagaimana peran pendidikan di sekolah dalam membina keimanan dan ketakwaan serta merubah watak dan kepribadian anak bangsa sesuai dengan tujuan pendidikan nasional. Hingga pada akhirnya terkesan bahwa usaha pembinaan keimanan dan ketakwaan bangsa adalah menjadi tugas dan tanggungjawab utama pendidikan di sekolah selain tentunya dari pendidikan di keluarga. Dengan demikian, baik negara, masyarakat maupun semua pihak harus berusaha untuk meningkatkan kualitas pendidikan di sekolah dan berupaya mengurangi bahkan sampai menghilangkan berbagai kelemahan serta kekurangan yang ada. Untuk itu salah satu tawaran pemecahan persoalan di atas adalah dengan penanaman nilai-nilai spiritual pada materi pelajaran, terutama dalam meteri ilmu pengetahuan alam. Metode analisis dalam tulisan ini mengadopsi prinsip-prinsip dasar pendidikan nilai dalam Islam yang berbasis pada integrasi keilmuan antara ilmu umum dengan ilmu agama. 


\section{PEMBAHASAN}

Integrasi nilai dalam pembelajaran/pendidikan merupakan proses bimbingan melalui suri tauladan guru yang berorientasi pada penanaman nilainilai kehidupan yang di dalamnya mencakup nilai-nilai agama, budaya, etika dan estetika menuju pembentukan peserta didik yang memiliki kecerdasan spiritualkeagamaan, pengendalian diri, kepribadian yang utuh, berakhlak mulia, serta keterampilan yang diperlukan dirinya, termasuk masyarakat dan negara (Sumantri, 2007: 134).

Mardiatmadja (Mulyana, 2004: 119) mendefinisikan integrasi nilai dalam pendidikan sebagai bantuan kepada peserta didik agar menyadari dan mengalami nilai-nilai serta menempatkannya secara integral dalam keseluruhan hidupnya. Pendidikan nilai tidak hanya merupakan program khusus yang diajarkan melalui sejumlah mata pelajaran, tetapi mencakup pula keseluruhan proses pendidikan. Dalam hal ini, yang menanamkan nilai kepada peserta didik bukan saja guru pendidikan nilai dan moral serta bukan saja pada saat mengajarkannya, melainkan kapan dan di manapun, nilai harus menjadi bagian integral dalam kehidupan.

Konsep integrasi menurut Sanusi (1987: 11) adalah suatu kesatuan yang utuh, tidak terpecah belah dan bercerai berai. Integrasi meliputi kebutuhan atau kelengkapan anggota-anggota yang membentuk suatu kesatuan dengan jalinan hubungan yang erat, harmonis dan mesra antara anggota kesatuan itu. Sedangkan yang dimaksud dengan integrasi nilai dalam pembelajaran adalah proses memadukan nilai-nilai tertentu terhadap sebuah konsep lain sehingga menjadi suatu kesatuan yang koheren dan tidak bisa dipisahkan atau proses pembauran hingga menjadi satu kesatuan yang utuh dan bulat (Sauri, tt: 3).

Dalam penjelasan lain, kesatuan koherensi antara pembelajaran IPA dan agama teraplikasi dalam bentuk: science matter integrated with religious matter (mengintegrasikan materi pelajaran umum dengan materi pelajaran pendidikan agama) yakni nilai-nilai Islami inklusif dalam penyampaian pembelajaran IPA atau sebaliknya religious matter integrated with science matter (mengintegrasikan materi pelajaran agama dengan mata pelajaran umum) yakni agama tidak mendeskriditkan ilmu pengetahuan alam. Integrasi nilai-nilai Islam terhadap ilmu juga berarti sebuah penyatuan antara ilmu pengetahuan dengan ilmu agama melalui beragam bentuk sarana dan suri tauladan dalam pembelajaran dengan tujuan utama agar peserta didik ketika mempelajari ilmu tersebut tidak hanya bertambah pengetahuannya, tapi juga berimplikasi pada pertambahan kesadaran akan lebih dekatnya peserta didik terhadap Tuhannya, hingga menjadikan perbaikan pada akhlaknya.

\section{Nilai-nilai Islam dalam Pembelajaran IPA}

Dalam tataran konseptual, integrasi nilai dalam pembelajaran IPA mengacu kepada pemahaman bahwa Ilmu pengetahuan apapun termasuk ilmu pengetahuan alam adalah sarana menuju Tuhan, jika manusia sejak dini 
menyadari bahwa kehidupan di dunia pada dasarnya untuk mencapai kehidupan di akhirat. Pada akhirnya, segala macam ilmu pengetahuan yang memberikan kebaikan di dunia dan di akhirat itu penting untuk dipelajari. Al-Ghazali menekankan perlunya manusia membuat skala prioritas pendidikan dengan menempatkan ilmu agama dalam posisi terpenting (Sholeh, 2006: 81). Namun demikian, kurikulum pendidikan Islam sampai saat ini masih dihadapkan pada kesulitan untuk mengintegrasikan dua kutub bidang keilmuan yakni ilmu umum dan ilmu agama. Pada satu sisi, harus berhadapan dengan 'subjek-subjek sekuler', dan pada sisis lain, dengan 'subjek-subjek keagamaan'. Subjek-subjek yang dianggap sekuler biasanya terdiri atas jenis keilmuan umum seperti matematika, fisika, biologi, kedokteran, sosiologi, ekonomi, politik, botani, zoologi, dan sebagainya. Sementara subjek-subjek keagamaan terdiri dari jenis sains wahyu seperti al-Quran, al-hadis, fikih, teologi, tasawuf, tauhid, dan semacamnya.

Dari dikotomi di atas, kurikulum pendidikan umum dan kurikulum pendidikan Islam masih berada pada wilayahnya masing-masing, sehingga proses pembelajarannya bersifat parsial dan terfragmentasi antara sains wahyu ilahi dan sains-sains alam. Padahal, menurut terminologi filsafat Islam, Tuhan menurunkan al-Quran-Nya dalam bentuk: al-Quran yang tertulis (recorded Qur'an), yaitu wahyu yang tertulis dalam lembaran buku yang dibaca oleh umat Islam setiap hari dan al-Quran yang terhampar (created Quran), yaitu alam semesta, jagat raya atau kosmologi ini. Oleh sebab itu dikotomi ini sebenarnya kurang tepat.

Berangkat dari pola pikir integratif, yaitu menyatukan arti kehidupan dunia dan akhirat, maka pendidikan umum pada hakikatnya adalah pendidikan agama juga, pendidikan IPA adalah pendidikan agama juga, dan begitu pula sebaliknya, pendidikan agama adalah juga pendidikan umum, pendidikan agama adalah pendidikan IPA. Idealnya tidak perlu terjadi persoalan ambivalensi dan dikotomik dalam orientasi pendidikan.

Pemahaman integrasi nilai-nilai Islam dalam pembelajaran IPA (sains) tersirat dalam al-Qur'an. Al-Quran tidak mempertentangkan antara sains dan agama. Bahkan dalam banyak ayat-Nya ditekankan agar manusia senantiasa memikirkan kejadian di alam untuk memperteguh keyakinan agamanya (Q.S. alAnbiyaa, 21: 30). Sains dalam hal ini juga bukan merupakan bagian yang terpisah dari agama. Sains merupakan bagian yang integral dari agama Islam. Al-Quran menyatakan bahwa sains, seperti halnya sains tentang kehidupan manusia merupakan bagian integral dari agama. Sains mengajarkan kepada manusia tentang bagaimana mengelola alam, melakukan berbagai proses, serta memproduksi sesuatu untuk kebutuhan hidup. Sementara itu agama mengajarkan manusia tentang sistem nilai. Agama mengajarkan tentang nilai ketakwaan terhadap Khaliq serta nilai kebaikan terhadap sesama.

Hal yang harus mendapatkan perhatian yaitu pernyataan bahwa Kitab Suci al-Qur'an berasal dari Allah yang memiliki kebenaran mutlak. Kebenaran yang mutlak ini menyebabkan al-Quran dapat dijadikan sebagai alat untuk menguji kebenaran prinsip-prinsip sains. Apabila penemuan sains bertentangan dengan 
al-Qur'an maka hal itu disebabkan karena masih sangat terbatasnya metode investigasi yang dapat dikembangkan oleh manusia. Dukungan terhadap pernyataan ini dikemukakan oleh Lawson (1995: 27), yang menyatakan bahwa terdapat dua perbedaan pendekatan yang esensial antara sains dan agama. Agama mempercayai sesuatu berdasarkan keyakinan, sementara sains mempercayai sesuatu berdasarkan evaluasi fakta dan penalaran. Meskipun demikian, kebenaran dalam agama adalah kekal sementara kebenaran dalam sains hanya bersifat tentatif (sementara). Oleh sebab itu sebenarnya antara agama dan ilmu pengetahuan alam bukanlah dua kutub yang tidak bisa dipertemukan. Bahkan boleh dikatakan saling bertautan dan sangat dekat. Agama dengan pendekatan melalui keyakinan mengartikan bahwa kebenaran yang dibawa adalah absolut, sudah jelas kebenarannya. Dengan demikian, ilmu pengetahuan memiliki tugas untuk menguji kebenaran tersebut, atau justru mencocokkan hasil dengan kebenaran tersebut. Artinya ada sesuatu yang sebenarnya bisa dipertemukan.

\section{Tujuan Integrasi Nilai-nilai Islam dalam Pembelajaran IPA di Sekolah}

Integrasi nilai-nilai Islam dalam pembelajaran sains (IPA) akan memberikan kekuatan pada ranah afektif, psikomotor dan kognitif. Tegasnya, manakala hal ini diimplementasikan dalam pembelajaran IPA di sekolah, akan memberikan hasil belajar siswa yang holistik dalam semua ranah belajarnya. Hal ini akan memberikan warna yang berbeda dari yang selama ini banyak terjadi dimana ranah kognitif begitu dominan atau bahkan menjadi satu-satunya yang dikembangkan dalam pembelajaran IPA di sekolah.

Pembelajaran IPA di sekolah masih minim integrasi dengan nilai-nilai islami baik model, metode, ataupun pendekatan pembelajaran, maka penting untuk menginterpretasikan kembali seluruh materi pelajaran sekolah dengan muatan-muatan nilai yang islami. Amanat konstitusi yang telah dijelaskan di atas tidak semata-mata mendorong siswa untuk mampu berkomunikasi tanpa bimbingan orang lain dan sekaligus dapat memecahkan masalah dengan baik, akan tetapi lebih sebagai jiwa atau ruh dari pendidikan itu. Sebagaimana pendidikan yang diajarkan Rasulullah Muhammad saw., yang lebih mengutamakan akhlak bagi ummatnya "li utammima makârim al-akblake."

Integrasi nilai-nilai dalam pembelajaran IPA di sekolah bertujuan untuk membantu mengembangkan kemahiran berinteraksi pada tahapan yang lebih tinggi serta meningkatkan kebersamaan dan kekompakan interaksi atau apa yang disebut Piaget sebagai ekonomi interaksi atau menurut Oser dinyatakan dengan peristilahan kekompakan komunikasi. Tujuan integrasi nilai tidak dapat tercapai tanpa aturan-aturan, indoktrinasi atau pertimbangan prinsip-prisnip belajar. Namun sebaliknya, dorongan moral komponen pembentukan struktur itu sangat penting. Oleh karena itu, pendidik seharusnya tidak hanya sekedar membekali dan menjejali siswa dengan pengetahuan tentang tujuan serta analisis dari hubungan antara tujuan dengan alat. 
Pentingnya integrasi nilai-nilai Islam dalam pembelajaran IPA menjadi satu kerangka normatif dalam merumuskan tujuan pendidikan sebagaimana diungkapkan Ali dan Luluk (2004: 267-274) bahwa tujuan penanaman nilai-nilai Islam: (1) mengembangkan wawasan spiritual yang semakin mendalam dan mengembangkan pemahaman rasional mengenai Islam dalam konteks kehidupan terutama yang berkaitan dengan ayat-ayat kauniyah (alam); (2) membekali siswa dengan berbagai kemampuan pengetahuan alam; (3) mengembangkan kemampuan pada diri siswa untuk menghargai dan membenarkan superioritas komparatif khazanah pengetahuan Islam di atas semua khazanah pengetahuan yang lain; (4) memperbaiki dorongan emosi melalui pengalaman imajinatif, sehingga kemampuan kreatif dapat berkembang dan berfungsi mengetahui norma-norma Islam yang benar dan yang salah; (5) membantu anak yang sedang tumbuh untuk belajar berpikir secara logis dan membimbing proses pemikirannya dengan berpijak pada hipotesis dan konsep-konsep pengetahuan alam yang dituntut.

\section{Implementasi Integrasi Nilai-nilai Islam dalam Pembelajaran IPA di Sekolah}

Agus Wasisto Dwi mengatakan dalam pendekatan SETSR (Sciencel, Environment, Social, Technology, and Religion) bahwa seorang guru, harus mampu mensinergikan penguasaan Iptek dan Imtak siswa, tanpa mengesampingkan salah satunya. Sebenarnya tidak terlalu sulit untuk menciptakan suatu pembelajaran yang dapat mengintegrasikan nilai-nilai agama dalam sebuah materi pelajaran. Dalam pelajaran apapun, seorang guru harus bisa memasukkan nilainilai agama seperti keimanan dan ketaqwaan. Pernyataan itu menyadarkan kita bahwa pendidikan agama, khususnya menumbuhkan iman dan taqwa dapat dilakukan dalam pelajaran apapun, tidak hanya dalam pelajaran agama.

Menumbuhkan sebuah kekaguman, sebagai awal dari iman dan ketaqwaan, dapat diintegrasikan dalam pelajaran Ilmu Pengetahuan Alam (IPA). IPA adalah pelajaran yang menekankan pada keterampilan proses (Iskandar, 1997: 5). Dalam menemukan fakta atau kejadian, siswa dituntut untuk aktif. Objek kajian IPA ada di sekitar kita, alam sekitar siswa. Dengan lingkungan sebagai media dan sumber belajar, maka siswa akan mudah melihat fenomena alam yang nantinya dapat mempertebal IMTAK siswa kepada Allah SWT. Pendidikan nilai ini mempergunakan pendekatan rasional ilmiah.

Materi Ilmu Pengetahuan Alam (IPA) yang ada di kurikulum sekolah berkaitan dengan cara mencari tahu (inquiry) tentang alam secara sistematis, sehingga IPA bukan hanya sebagai penguasaan kumpulan pengetahuan yang berupa fakta-fakta, konsep-konsep atau prinsip-prinsip saja, tetapi juga merupakan suatu proses penemuan. Pendidikan IPA di sekolah diharapkan dapat menjadi wahana bagi peserta didik untuk mempelajari diri sendiri dan alam sekitar, prospek pengembangan lebih lanjut dalam menerapkannya di dalam kehidupan sehari-hari, serta lebih menghayati akan keagungan ciptaan Allah swt. 
Sebagaimana yang Allah swt firmankan dalam Surat Ali Imran (3) ayat 191 yang artinya:

"(yaitu) orang-orang yang mengingat Allah sambil berdiri atau duduk atau dalam keadaan berbaring dan mereka memikirkan tentang penciptaan langit dan bumi (seraya berkata): "Ya Tuhan kami, tiadalah Engkau menciptakan Ini dengan sia-sia, Maha Suci Engkau, Maka peliharalah kami dari siksa neraka.

Ayat di atas memberi isyarat bahwa dengan adanya perenungan dan penyadaran akan Sang Pencipta yang menjadi sebab makhluk untuk percaya akan peran superaktif dari Sang Khalik. Aktivitas tersebut sebenarnya adalah aktivitas ilmiah karena menunjukkan adanya integrasi yang dapat menjadi landasan dalam pembelajaran. Integrasi yang diisyaratkan dalam ayat di atas adalah integrasi antara berdzikir dan berfikir sehingga menjadikan pembelajaran tersebut kaya akan penanaman nilai-nilai religi dalam afektif siswa. Manakala berdzikir terhadap Sang Khalik dan berpikir atas penciptaan-Nya, menjadikan siswa seorang hamba Tuhan yang senantiasa bersyukur dan bertasbih atas keagungan ciptaan-Nya yaitu ayat-ayat kauniyah yang terhampar di alam semesta dan berkata "tiadalah satupun yang sia-sia yang telah Engkau ciptakan."Apalagi pembelajaran IPA menekankan pada eksplorasi pengalaman langsung untuk mengembangkan kompetensi agar peserta didik menjelajahi dan memahami alam sekitar secara ilmiah yang terintegrasi dengan nilai-nilai spiritual. Pembelajaran IPA diarahkan untuk mencari tahu dan berbuat sehingga dapat membantu peserta didik untuk memperoleh pemahaman yang lebih mendalam tentang dirinya sendiri dan alam sekitar serta posisi kehambaanya di hadapan Tuhan.

Pembelajaran IPA menyediakan berbagai pengalaman belajar untuk memahami konsep dan proses sains. Keterampilan proses ini meliputi keterampilan mengamati, mengajukan hipotesis, menggunakan alat dan bahan secara baik dan benar dengan selalu mempertimbangkan keamanan dan keselamatan kerja, mengajukan pertanyaan, menggolongkan dan menafsirkan data, serta mengkomunikasikan hasil temuan secara lisan atau tertulis, menggali dan memilah informasi faktual yang relevan untuk menguji gagasan-gagasan atau memecahkan masalah sehari-hari.

Kegiatan pembelajaran IPA lebih diarahkan kepada kegiatan yang mendorong siswa belajar aktif. Dalam pemilihan pendekatan pembelajaran IPA guru selalu mempertimbangkan tentang fasilitas sekolah yang ada, misalnya laboratorium serta sumber belajar lainnya. Ada beberapa pendekatan yang bisa dipertimbangkan dalam melakukan pembelajaran antara lain: (1) pendekatan konsep; (2) pendekatan ketrampilan proses; (3) pendekatan pemecahan masalah; (4) pendekatan induktif dan deduktif dan (5) pendekatan lingkungan (Depag, 1996: 81). Di samping pendekatan-pendekatan tersebut ada pendekatan dalam pembelajaran yang cenderung bersifat integratif dalam memandang suatu permasalahan yaitu pendekatan SETS (Science, Environment, Technology, and Society) yang ditambah dengan sudut pandang agama Islam yang bersumber pada al- 
Qur'an dan Sunnah Rasul. Pendekatan integratif merupakan usaha untuk menjadikan lulusan pendidikan setidaknya tahu tentang atau bahkan menyukai Science dan Technology, perkembangan serta implikasinya terhadap lingkungan, masyarakat, peningkatan keimanan dan ketaqwaan.

Dalam mengimplementasikan konsep integrasi nilai dalam pembelajaran IPA dalam pembelajaran di sekolah, guru dapat merujuk referensi yang ditawarkan Bagir, dkk. (Sauri, tt: 11) yang membaginya ke dalam empat tataran implementasi, yakni: tataran konseptual, institusional, operasional, dan arsitektural.

Dalam tataran konseptual, integrasi nilai dalam pembelajaran dapat diwujudkan melalui perumusan visi, misi, tujuan dan program sekolah (rencana strategis sekolah). Adapun secara institusional, integrasi dapat diwujudkan melalui pembentukan institution culture yang mencerminkan paduan antara nilai dan pembelajaran. Sedangkan dalam tataran operasional, rancangan kurikulum dan esktrakulikuler (Kurikulum Tingkat Satuan Pendidikan/KTSP) harus diramu sedemikian rupa sehingga nilai-nilai fundamental agama dan ilmu terpadu secara koheren. Sementara secara arsitektural, integrasi dapat diwujudkan melalui pembentukan lingkungan fisik yang berbasis iptek dan imtak, seperti sarana ibadah yang lengkap, sarana laboratorium yang memadai, serta perpustakaan yang menyediakan buku-buku agama dan ilmu umum secara lengkap.

Menurut Suwarna (2007: 33-37), dalam mengevaluasi proses integrasi nilai dalam pembelajaran, guru dapat menggunakan teknik penilaian $5 \mathrm{P}$ (papers and pencils, portfolio, project, product, and performance. Penilaian 5 P ini benar-benar diarahkan pada konteks integrasi nilai dalam keluarga, sekolah, dan masyarakat. Penilaian paper \& pencils adalah penilaian tertulis. Hendaknya tes-tes tertulis juga mempertanyakan nilai-nilai yang terkandung di dalamnya. Portofolio merupakan kumpulan tugas, prestasi, keberadaan diri atau potret diri keseharian pembelajar. Wujud tugas portofolio ada yang berjenjang ada pula yang deskrit (terpisah). Project merupakan tugas terstruktur. Sebagai tugas terstruktur, project bersifat wajib. Hal ini biasanya terkait dengan fenomena pendidikan nilai yang harus dikaji, dianalisis, dan dilaporkan oleh pembelajar. Sementara yang dimaksud product adalah hasil karya pembelajar atas kreativitasnya. Pembelajar dapat membuat karya-karya kreatif atas inisiatif sendiri, misalnya menghasilkan cerita pendek, karikatur atau membuat puisi yang memuat budi pekerti. Sedangkan yang dimaksud dengan performance atau performansi adalah penampilan diri. Sebenarnya, hakikat dari pendidikan nilai adalah realisasi budi pekerti luhur dalam berbicara, bertindak, berperasaan, bekerja, dan berkarya, pendek kata cipta, rasa, dan karsa dalam kehidupan sehari-hari. Jika pembelajar telah dapat menampilkan budi pekerti luhur, berarti internalisasi dan aplikasi pendidikan nilai telah tercapai.

Dalam mengembangkan pembelajaran IPA yang terintegrasi nilai-nilai Islam (agama), diperlukan suatu pedoman yang dapat digunakan untuk menerapkan dalam pembelajaran tersebut. Untuk itu diperlukan Broad Curriculum (Integrated Curriculum). Kurikulum yang terpadu pada pembelajaran dengan nilainilai Islam sangat diperlukan untuk mempermudah guru dalam mengimplementasikannya. Pengejawantahan kurikulum yang terpadu pada 
proses pembelajaran, tentunya tidak terlepas dari bagaimana strategi belajar mengajar yang hendak disampaikan pada siswa, hal ini juga terkait dengan metode dan pendekatan apa yang harus digunakan. Suharsimi Arikunto (1993: 306-307) mendefinisikan metode, pendekatan dan strategi belajar mengajar adalah:

Cara-cara atau teknik yang digunakan dalam mengajar, misalnya; ceramah, tanya jawab, diskusi sosiodrama, demonstrasi, dan eksperimen. Pendekatan lebih menunjukan pada bagaimana kelas dikelola, misalnya secara individu, kelompok dan klasikal. Steategi pembelajaran menunjuk kepada bagaimana guru mengatur keseluruhan proses belajar mengajar, meliputi: mengatur waktu, pemenggalan penyajian, pemiliham metode, dan pemilihan pendekatan.

Dengan mengetahui metode, pendekatan pembelajaran terpadu yang digunakan maka pada prosesnya dapat mencapai target dan tujuan "nilai" pendidikan yang diharapkan. Pendidikan nilai bertujuan untuk menentukan sikap atau tingkah laku seseorang. Atmadi (2001: 82) mengungkapkan bahwa metode yang ditempuh untuk mencapai tujuan pendidikan nilai tersebut antara lain:

1. Metode menasihati (moralizing) yaitu metode pendidikan nilai di mana seorang pendidik secara langsung mengajarkan sejumlah nilai yang harus menjadi pegangan hidup peserta didik. Dalam metode ini pendidik dapat menggunakan khutbah, berpidato, memberi nasehat atau memberi instruksi kepada peserta didik agar menerima saja sejumlah nilai sebagai pegangan hidup.

2. Metode serba membiarkan (a laissezfaire attitude), yaitu metode pendidikan nilai di mana seorang pendidik memberi kesempatan seluas-luasnya kepada peserta didik untuk menentukan pilihan terhadap nilai-nilai yang ditawarkan oleh pendidik. Pendidik hanya memberikan penjelasan tentang nilai-nilai tanpa memaksakan kehendaknya sendiri bahwa nilai ini atau itu yang seharusnya dipilih oleh peserta didik tetapi setelah memberi penjelasan pendidik mempersilahkan peserta didik mengambil sikap sendiri-sendiri.

3. Metode model (modelling) yaitu metode pendidikan nilai di mana seorang pendidik mencoba meyakinkan peserta didik bahwa nilai tertentu itu memang baik dengan cara memberi contoh dirinya atau seseorang sebagai model penghayat nilai tertentu, pendidik berharap peserta didik tergerak untuk menirunya.

Metode pendidikan nilai yang dipakai oleh Sutajo Adisusilo (Atmadi, 2001: 71-91) adalah metoda VCT (Value Clarification Technique). VCT adalah teknik pengungkapan nilai. Dengan metode ini nilai tidak diajarkan secara doktriner, namun disimpulkan atau ditemukan sendiri oleh peserta didik dari sejumlah kegiatan pengajaran. VCT merupakan cara atau proses di mana pendidik membantu orang atau peserta didik menemukan nilai-nilai yang melatarbelakangi tingkah lakunya serta pilihan-pilihan penting yang dibuatnya. Dalam kenyataannya peserta didik atau orang harus terus-menerus menentukan nilai 
sebagai dasar tindakannya. VCT akan mengantar peserta didik mempunyai keterampilan atau kemampuan menentukan pilihan yang tepat sesuai tujuan hidupnya. Salah satu metode VCT adalah dengan penyisipan pertanyaan dalam suatu kegiatan belajar mengajar. Maksudnya, ada pertanyaan tentang nilai yang sengaja disisipkan di awal, di tengah, atau di akhir pengajaran suatu mata pelajaran.

Bentuk pertanyaan VCT beraneka ragam sesuai dengan tujuan yang diharapkan pendidik, diantaranya ialah pertanyaan penjajagan (di awal pengajaran, di tengah, atau akhir pengajaran untuk pengecekan hasil sementara atau hasil akhir). Lontaran pertanyaan jenis ini bila terjawab oleh peserta didik, hendaknya jangan disusul oleh pertanyaan mencari alasan atau reasoning sebelum jumlah penjawab sesuai dengan harapan kita. Penghargaan (berupa pujian) jangan dahulu diberikan sebelum jumlah penjawab yang diharapkan terpenuhi. Penjajagan dan klarifikasi serta pertanyaan untuk mencari alasan yang dilakukan dalam proses belajar mengajar bukanlah performance test, dan jangan diberi nilai, karena membenihkan nilai jawaban demi jawaban akan mengunci dan membatasi anak dalam menjawab (Atmadi, 2001: 82-83).

Proses penilaian merupakan proses yang utama dalam pengembangan nilai dalam pembelajaran. Ada enam alternatif pendekatan bagi terjadinya proses valuing dalam pembelajaran antara lain pendekatan untuk pengembangan kognitif, penanaman nilai, perkembangan moral, kejelasan nilai-nilai (value clarification), belajar tindakan (action learning), dan analisis. Pendekatan pengembangan kognitif akan lebih memberikan kesempatan pada siswa untuk mampu mengembangkan pola-pola penalaran yang lebih kompleks didasarkan pada seperangkat nilai. Pendekatan penanaman nilai lebih bersifat indoktrinasi dalam pengembangan nilai. Proses valuing dengan pendekatan ini lebih merupakan internalisasi nilai-nilai tertentu yang dimiliki guru dan masyarakat kepada diri anak atau mengubah nilai-nilai anak ke arah nilai-nilai tertentu yang dikehendakinya. Pendekatan perkembangan moral membantu anak mengembangkan penalaran moralnya melalui penggunaan episode dilema moral sebagaimana yang dikembangkan Lawrence Kohlberg (1973: 630-646; 1983: 192). Pendekatan kejelasan nilai-nilai memberikan kesempatan kepada anak untuk menyadari dan mengenal nilai-nilainya dan juga nilai orang lain, serta mengkomunikasikan secara terbuka nilai-nilai mereka. Tujuan utama pendekatan belajar tindakan ialah memberi kesempatan kepada anak untuk melakukan tindakan-tindakan yang sesuai dengan nilai-nilainya melalui permainan peran, simulasi, diskusi dan sebagainya. Pendekatan analisis menyediakan pengalaman belajar menggunakan pemikiran logis serta penyelidikan ilmiah untuk mengevaluasi isu-isu melalui diskusi, melakukan penyelidikan dan analisis kasus (Firman, 1988: 29).

Mata pelajaran IPA dikembangkan melalui kemampuan berpikir analitis, induktif, dan deduktif untuk menyelesaikan masalah yang berkaitan dengan peristiwa alam sekitar. Penyelesaian masalah yang bersifat kualitatif dan 
kuantitatif dilakukan dengan menggunakan pemahaman dalam bidang matematika, fisika, kimia dan pengetahuan pendukung lainnya. Hal ini sejalan dengan banyak isyarat-isyarat ilmiah di dalam al-Qur'an yang terkait dengan ayatayat tentang alam (kauniyah) yang menyuruh hamba-Nya untuk berfikir (tafakearu) dan memperhatikan/melihat (yandzuruuna) terutama alam semesta. Untuk itu, yang bisa dilakukan guru misalnya, sebagaimana yang dikutip dari buku Steve Parker (2005: 26) ada lebih dari seratus juta gelembung udara (alveoli) yang sangat kecil di setiap paru-paru. Dari fakta tersebut dapat kita kembangkan sikap siswa untuk mengagumi, bahwa dalam tubuhnya terdapat sebuah mesin yang sangat penting bagi kehidupan. Mesin alami yang terdiri dari seratus juta lebih alveoli. Tentu sebanyak itu bukan jumlah yang sedikit dan benar-benar mengesankan. Anugerah dari Allah swt untuk kita, manusia. Selain itu dituliskan oleh Steve Parker (2005: 31) sebagai berikut Kaktus tidak memiliki daun lebar untuk membuat makanan, karena akan menghilangkan banyak air. Sebagai gantinya, kaktus menggunakan batang yang tebal, hijau, dan berdaging sebagai daun untuk menyimpan air dan mengubah cahaya matahari menjadi makanan.

Guru dapat memetik pelajaran dari kutipan di atas yang nantinya dapat diajarkan kepada siswa. Allah swt adalah kesempurnaan dari segalanya. Dia menciptakan segala sesuatunya dengan kebermanfaatan. Bunga mawar lebih indah daripada tanaman kaktus. Akantetapi ternyata ada kelebihan dari tumbuhan kaktus, yaitu dapat hidup di gurun pasir yang gersang. Subhanallah, betapa kita tidak bisa memungkiri kekuasaan-Nya.Seperti yang telah difirmankan Allah swt dalam Q.S. al-Jaatsiyah (45: 3):

Sesunggubnya pada langit dan bumi benar-benar terdapat tanda-tanda (kekuasaan Allah) untuk orang-orang yang beriman.

Dalam materi tentang tata surya, guru juga dapat menyisipkan nilai keimanan. Tata surya terdiri dari planet-planet, bintang, satelit, asteroid, dan meteorit. Matahari adalah pusat dari tata surya. Semuanya berjalan sesuai garis edarnya. Berotasi dan berevolusi sesuai dengan lintasan dan waktu yang berbedabeda. Kesemuanya itu telah diatur oleh Allah swt. Apabila tidak ada yang mengatur maka planet-planet itu akan bertabrakan satu sama lain.

Allah-lah yang meninggikan langit tanpa tiang (sebagaimana) yang kamu lihat, Kemudian dia bersemayam di atas 'Arasy, dan menunduk.kan matahari dan bulan. masing-masing beredar hingga waktu yang ditentukan. Allah mengatur urusan (makblukNya), menjelaskan tanda-tanda (kebesaran-Nya), supaya kamu meyakini pertemuan (mu) dengan Tubanmu (Q. S. Ar-Ra'd, 13:2).

Contoh nilai religius lain yang dapat dikembangkan dari pembelajaran konsep IPA yaitu sistem peredaran darah pada manusia menurut Rebecca Pratt (2000: 231) antara lain: Arsitektur struktur arteri dan vena disesuaikan dengan fungsinya. Arteri berhubungan langsung dengan vena pada bagian kapiler dan 
venula yang dihubungkan oleh bagian endotheliumnya. Arteri dan vena terletak bersebelahan. Dinding arteri dan vena mempunyai tiga lapisan yaitu lapisan bagian dalam yang terdiri dari endothelium, lapisan tengah yang terdiri atas otot polos dengan serat elastis dan lapisan paling luar yang terdiri atas jaringan ikat ditambah dengan serat elastis. Cabang terkecil dari arteri dan vena disebut kapiler. Pembuluh kapiler memiliki diameter yang sangat kecil dan hanya memiliki satu lapisan tunggal endothelium dan sebuah membran basal. Perbedaan struktur masing-masing pembuluh darah berhubungan dengan perbedaan fungsional masing-masing pembuluh darah tersebut. Arteri berdinding tebal karena harus memompa darah dari jantung ke seluruh tubuh. Dengan demikian, agar dinding arteri tidak jebol (pecah) karena tekanan yang tinggi maka dindingnya harus tebal dan kuat. Vena berdinding tipis dan mempunyai katup berfungsi mengalirkan darah menuju ke jantung. Pembuluh ini berdinding tipis karena hanya memerlukan tekanan untuk membawa darah ke jantung. Pembuluh vena dilengkapi dengan katup untuk menjaga agar darah tidak mengalir mundur. Struktur kedua pembuluh darah yang sempurna sesuai dengan fungsinya ini menunjukkan tanda-tanda kebesaran Allah serta Maha kaya-Nya ilmu Allah dalam mengatur suatu kesatuan organ yang berfungsi dengan baik. Berkenaan dengan hal tersebut, Allah swt berfirman, yang artinya:

Dan tidak ada sesuatupun melainkan pada sisi Kami-lab khazanabnya; dan kami tidak. menurunkannya melainkan dengan ukuran yang tertentu (Q.S. al-Hijr: 21).

Dalam ayat lain disebutkan;

Yang telah menciptakan kamu lalu menyempurnakan kejadianmu dan menjadikan (susunan tubub) mu seimbang (Q.S. al-Infithaar [8]): 7).

Nilai-nilai Imtak dapat diajarkan kepada siswa antara lain melalui pembelajaran biologi alat indera. Melalui pembelajaran ini siswa dapat diberikan pemahaman bahwa alat indera merupakan anugrah dari Allah swt agar manusia bersyukur dengan cara menggunakannya untuk mencari kebenaran dan keyakinan terhadap ayat-ayat Allah, baik ayat kauliyah maupun ayat kauniyah. Selain dari itu siswa diajak untuk menggunakan alat indera dalam rangka mencari keridaan Allah, tidak menggunakannya untuk keburukan, karena semuanya akan dimintai pertanggungjawaban oleh Allah. Tentunya masih banyak lagi bukti kekuasaan Allah swt yang dapat dambil kebermaknaannya oleh guru untuk siswa. semuanya tergantung kepada guru sebagai penanam nilai-nilai religi dalam pembelajaran IPA. Harapannya, guru mampu menyelaraskan antara penguasaan Iptek dan Imtak siswa.

Tidak ada yang salah dengan pembelajaran IPA di sekolah jika pola penanaman nilai-nilai Islam yang sebenarnya betul-betul diterapkan. Tidak dapat dikatakan Islami apabila pola pembelajaran IPA yang kental dengan pesan moralitas sangat kurang porsinya, karena telah dinyatakan dalam al-Quran bahwa berbagai fakta penciptaan di alam hanya dapat dipahami dengan pengetahuan dan teknologi. Seandainya seorang muslim berpegang teguh pada al-Quran dan 
hadis, maka mempelajari sains dengan baik merupakan hal yang wajib. Dengan demikian, dalam mempelajari nilai-nilai kehidupan melalui sains, aspek penguasaan konsep sains dan teknologi tetap harus mendapat penekanan. Tidak ada pendidikan yang disebut islami apabila pendidikan tersebut tidak menempatkan sains sebagai komponen sangat penting (Ali dan Luluk, 1996: 45). Nilai religius suatu bahan ajar dalam IPA adalah kandungan nilai yang dapat meningkatkan keyakinan terhadap Allah. Keteraturan, keseimbangan, peristiwa sebab akibat, dan lain sebagainya merupakan aspek yang dapat menumbuhkan kesadaran bahwa segala hal yang terjadi mesti ada yang menciptakan dan mengaturnya. Sains atau IPA merupakan cara tepat untuk mengenal Allah. Pengamatan ilmiah terhadap aspek-aspek kehidupan dapat memperkenalkan manusia terhadap misteri penciptaan, dan akhirnya mengarah pada pengenalan pengetahuan, kebijakan, dan kekuasaan tanpa batas yang dimiliki Allah.

\section{SIMPULAN}

Alam adalah suatu bukti yang nyata tentang keagungan Allah swt. Ciptaan yang begitu indah dan mengesankan tentu arsiteknya adalah sesuatu yang Maha Segalanya. Lebih sempurna dari segala sesuatu yang diciptakan-Nya. Dengan menerapkan pembelajaran IPA di sekolah umum berbasis Imtak, diharapkan akan tertanam suatu sikap percaya, mengimani, dan taqwa kepada Allah swt. Upaya terintegrasinya pembelajaran IPA dengan nilai-nilai Islam tidak terlepas dari keilmuan yang harus diterapkan dalam proses pembelajaran tanpa mengedepankan independensi keilmuan. Integrasi nilai-nilai Islam tersebut terwujud dalam keutuhan kerangka nilai Islam pada pembelajaran IPA di sekolah terintegrasi secara menyeluruh (integral-holisik), keragaman model, metode dan pendekatan terpadu dengan nilai-nilai Islam sebagai kerangka normatif dapat dijadikan perspektif baru bagi para pendidik dalam melaksanakan proses pembelajaran IPA serta keterpaduan penyelenggaraan pendidikan yang mengharuskan nilai-nilai Islam pada pembelajaran IPA di sekolah teraplikasikan secara integrated dengan kebutuhan masyarakat dan keluarga. Pada realitasnya integrasi nilai-nilai Islam dalam pembelajaran IPA dapat menghapus pembelajaran yang bersifat paradoks antara ketiga unsur tersebut sehingga berimplikasi terhadap peningkatan kualitas (nilai) tanggungjawab moral dan akhlak siswa.

\section{DAFTAR PUSTAKA}

Arikunto, Suharsimi. 1993. Manajemen Penelitian. Jakarta: PT. Raja Grafindo

Atmadi, A. 2001.Transformasi Pendidikan Memasuki Millennium Ketiga. Yogyakarta:Depdiknas.

Firman, Harry. 1991. Penilaian Hasil Belajar dalam Pengajaran Kimia. Bandung:Jurusan Pendidikan Kimia IKIP Bandung.

Iskandar, Srini M. 1997. Pendidikan Ilmu Pengetabuan Alam. Bandung: CV Maulana. 
Lawson, A.E. 1995. Science Teaching and the Development of Thinking. Belmont, CA: Wadsworth.

Masnun, Mohammad. 2007. Pendidikan Agama Islam dalam Sorotan. VOl. 13 No. 2 Desember 2007. Cirebon: Jurnal Pendidikan Islam Lektur.

M., Ali dan Luluk Y. R., 2004. Paradigma Pendidikan Universal di Era Modern dan Post-Modern; Mencarai "Visi Baru" atas "Realitas Baru" Pendidikan Kita.Yogyakarta: Institute for Religion and Civil Society Development (Ircisod).

Muhaimin. 2009. Pengembangan Kurikulum Pendidikan Agama Islam di Sekolah, Madrasah, dan Perguruan Tinggi. Jakarta: RajaGrafindo Persada. . 2006. Nuansa Baru Pendidikan Islam Mengurai Benang Kusut Dunia Pendidikan. Jakarta: RajaGrafindo.

Mulyana, R. 2004. Mengartikulasikan Pendidikan Nilai. Bandung: Alfabeta.

Parker, Steve. 2005. How the Body Works. New York: Reader's Digest Association

Pratt, Rebecca. 2000. "Cardiovascular System: Blood" dalam Journal of Anatomy One. Salt Lake City, UTAH: Amirsys, Inc.

Sanusi, S. 1987. Integrasi Umat Islam. Bandung: Iqomatuddin.

Sauri, S (tt). Integrasi Imtak dan Imptek Dalam Pembelajaran. Makalah: Tidak diterbitkan.

Sholeh, Asrorun Ni'am. 2006. Membangun Profesionalitas Guru: Analisis Kronologis atas Labirnya UU Guru dan Dosen. Jakarta: eLSAS.

Sumantri, E. 2007. Pendidikan Nilai Kontemporer. Bandung: Program Studi PU UPI.

Suwarna. 2007. "Strategi Integrasi Pendidikan Budi Pekerti dalam Pembelajaran Berbasis Kompetensi", Jurnal Cakrawala Pendidikan. (Online) Tersedia: http://eprints.uny.ac.id/482/1/strategi_integrasi.pdf (2 Mei 2013)

UUD 1945. 2002. Hasil Amandemen ke-IV Tahun 2002. Surakarta: al-Hikmah.

UU RI No.20 Tahun 2003 Tentang Sistem Pendidikan Nasional. Jakarta: Sinar Grafika. 